\title{
Effects of Exogenous $N$-Acyl-Homoserine Lactone as Signal Molecule on Nitrosomonas Europaea under ZnO Nanoparticle Stress
}

\author{
Junkang $\mathrm{Wu}^{1,2}$, Huan Gao ${ }^{1,2}$, Jinyu Ye ${ }^{1,2}$, Yan Chang ${ }^{1,2}$, Ran $Y u^{1,2, *(\mathbb{D})}$, Zhen Ding ${ }^{3, *}$ and \\ Guangcan Zhu 1,2 \\ 1 Department of Environmental Science and Engineering, School of Energy and Environment, \\ Southeast University, Nanjing 210096, Jiangsu, China \\ 2 Key Laboratory of Environmental Medicine Engineering, Ministry of Education, Southeast University, \\ Nanjing 210009, Jiangsu, China \\ 3 Jiangsu Province Center for Disease Control and Prevention, Nanjing 210009, Jiangsu, China \\ * Correspondence: yuran@seu.edu.cn (R.Y.); hfdz@jscdc.cn (Z.D.); \\ Tel.: +86-15312083786 (R.Y.); +86-18915999356 (Z.D.)
}

Received: 16 July 2019; Accepted: 17 August 2019; Published: 20 August 2019

\begin{abstract}
Despite the adverse effects of emerging $\mathrm{ZnO}$ nanoparticles (nano- $\mathrm{ZnO}$ ) on wastewater biological nitrogen removal (BNR) systems being widely documented, strategies for mitigating nanoparticle (NP) toxicity impacts on nitrogen removal have not been adequately addressed. Herein, $N$-acyl-homoserine lactone (AHL)-based quorum sensing (QS) was investigated for its effects against nano-ZnO toxicity to a model nitrifier, Nitrosomonas europaea. The results indicated that AHL-attenuated nano-ZnO toxicity, which was inversely correlated with the increasing dosage of AHL from 0.01 to $1 \mu \mathrm{M}$. At $0.01 \mu \mathrm{M}$, AHL notably enhanced the tolerance of $N$. europaea cells to nano-ZnO stress, and the inhibited cell proliferation, membrane integrity, ammonia oxidation rate, ammonia monooxygenase activity and $a m o A$ gene expression significantly increased by $18.2 \pm 2.1$, $2.4 \pm 0.9,58.7 \pm 7.1,32.3 \pm 1.7$, and $7.3 \pm 5.9 \%$, respectively, after $6 \mathrm{~h}$ of incubation. However, increasing the AHL dosage compromised the QS-mediated effects and even aggravated the NPs' toxicity effects. Moreover, AHLs, at all tested concentrations, significantly increased superoxide dismutase activity, indicating the potential of QS regulations to enhance cellular anti-oxidative stress capacities when facing NP invasion. These results provide novel insights into the development of QS regulation strategies to reduce the impact of nanotoxicity on BNR systems.
\end{abstract}

Keywords: ZnO nanoparticle; Nitrosomonas europaea; quorum sensing; stress tolerance; acyl-homoserine lactone

\section{Introduction}

In recent decades, engineered nanomaterials have become an emerging class of materials [1]. Diverse metallic nanoparticles (MNPs), displaying unique physical and chemical characteristics, have been broadly applied in commercial and industrial products, such as electronics, catalysts, pharmaceuticals, pigments, cosmetics, and textiles [2]. ZnO NPs (nano-ZnO), which have high water solubility, are among the most commonly used NPs, according to the Organization for Economic Cooperation and Development [3]. Due to the unique optoelectronic and catalytic properties [4], $\mathrm{ZnO}$ and nano-ZnO have been widely applied in many products, including solar cells, electronic sensors, antibacterial agents, photocatalysts, sunscreen, batteries, and glass [5-7]. The increasing use of MNPs and their inevitable emissions into the environment [8] have caused an increase in research focus on their bio-safety and risks to ecosystems $[5,9]$. 
As one of the most important environmental intermediates, the biological wastewater treatment plant is considered as a potential NP sink [10]. It has been estimated that the concentrations of nano-ZnO in the sewage-activated sludge are 31-200 mg/kg in Europe [11]. As a result, the retained nano-ZnO have been widely reported to decrease microbial community diversity, impair respiration rates of nitrifiers and heterotrophic bacteria, and inhibit nitrogen removal in biological nitrogen removal (BNR) systems [11,12]. In particular, ammonia-oxidizing bacteria (AOB) and ammonia oxidation activity have been shown to be vulnerable to nano- $\mathrm{ZnO}$ stress [11,13]. Given the foreseeable adverse effects of nano-ZnO on BNR processes, strategies for relieving NP toxicity to ensure stable BNR performance should be developed. Several studies have proposed physical or chemical methods to alleviate MNP toxicity, mainly by reducing the bioavailability of MNP and/or metal ion solubility [14,15] or adjusting environmental conditions (e.g., light intensity, substrate composition, and ion strength) [11,16]. However, strategies for enhancing microbial resistance to MNPs have seldom been reported.

Bacterial quorum sensing (QS) is a method of signalling transduction based on cell-cell communication processes. QS regulation mechanisms involve producing and sensing small signal molecules called autoinducers (AI), such as $N$-acyl-homoserine lactones (AHLs) [17]. When AHL concentrations reach a threshold value, bacterial communities coordinate their behaviour as a group by activating the expression of specific genes [18]. AHL-based QS regulation has been shown to commonly occur among nitrifiers in BNR systems [19]. For example, exogenous dosing of AHLs into BNR systems has been reported to favour the growth and metabolism of autotrophic nitrifiers [20], increase the ammonia oxidation rate (AOR) [21], and promote extracellular polymeric substance production [22]. In addition, QS regulation has been shown to actively participate in antibiotic resistance [17] and bacterial adaptive responses under graphene oxide stress [23]. Moreover, it has been found that Ag NPs could significantly decrease AHL concentrations and interrupt QS regulation in Gram-negative bacteria [24]. Therefore, we hypothesized that exogenous AHLs addition would be able to mediate NP biotoxicity.

The objectives of this study were to exam the impacts of a typical exogenous QS signalling molecule, $\mathrm{N}$-3-oxo-hexanoyl-homoserine lactone (3-oxo- $\mathrm{C}_{6}$-HSL) addition on nano- $\mathrm{ZnO}$ toxicity to a model AOB, Nitrosomonas europaea [25], which produces at least three types of AHL, including $\mathrm{C}_{6}$-HSL, $\mathrm{C}_{8}-\mathrm{HSL}$, and $\mathrm{C}_{10}-\mathrm{HSL}$ [26]. The effects of 3-oxo- $\mathrm{C}_{6}$-HSL on N. europaea cells' proliferation rate, membrane integrity, AOR, and ammonia monooxygenase (AMO) activity were assessed when exposed to nano- $\mathrm{ZnO}$ in the short-term $(6 \mathrm{~h})$. Moreover, quantitative reverse transcription polymerase chain reaction (qRT-PCR) analysis was performed to quantify amo $A$ gene expressions under nano-ZnO stress in cooperation with QS regulation.

\section{Materials and Methods}

\subsection{Bacterial Strain}

N. europaea ATCC 19718 strain was obtained from American Type Culture Collection and continuously cultured in a chemostat bioreactor at $25^{\circ} \mathrm{C}$ in the dark. The working volume and hydraulic retention time in the chemostat were designed to be $3 \mathrm{~L}$ and $2.2 \mathrm{~d}$, respectively. The $\mathrm{pH}$ in the reactor was controlled between 7.4-7.5 via automatic addition of $100 \mathrm{~g} / \mathrm{L}$ sterile $\mathrm{NaHCO}_{3}$ with a Meller $\mathrm{pH}$ controller (Taiwan, China). The dissolved oxygen (DO) concentration was maintained around $2 \mathrm{mg} / \mathrm{L}$ by aeration of filter-sterilized air. The culture medium was the same as that used in our previous publication [27], which contained $20 \mathrm{mM} \mathrm{NH}_{4}-\mathrm{N}, 0.5 \mathrm{mM} \mathrm{K}_{2} \mathrm{HPO}_{4}, 0.8 \mathrm{mM} \mathrm{MgCl}_{2}, 10 \mathrm{mM}$ 3-[4-(2-hydroxyethyl)-1-piperazine] propanesulfonic acid, $0.1 \mathrm{mM} \mathrm{CaCl}_{2}, 2.4 \mu \mathrm{M}$ EDTA-Fe ${ }^{3+}, 1 \mu \mathrm{M}$ $\mathrm{CuCl}_{2}, 0.9 \mu \mathrm{M} \mathrm{MnSO}_{4}, 0.4 \mu \mathrm{M} \mathrm{Na}_{2} \mathrm{MoO}_{4}, 0.3 \mu \mathrm{M} \mathrm{ZnCl}_{2}$, and $0.02 \mu \mathrm{M} \mathrm{CoSO}_{4}$.

\subsection{Chemicals and Nano-ZnO Characterization}

$\mathrm{C}_{6}$-oxo-HSL and nano-ZnO were bought from Sigma-Aldrich (St. Louis, MO, USA). A $\mathrm{C}_{6}$-oxo-HSL stock solution (10 g/L) was prepared in dimethylsulfoxide (DMSO) [28], since AHLs are not soluble in water. The average primary and hydrodynamic diameter size (in DI water) of the NPs were determined 
using a JSM-6390 scanning electron microscope (SEM, Electronics Co., Ltd., Tokyo, Japan) and a Nano ZS90 analyser (Malvern, Worcestershire, UK), respectively as described previously [29].

\subsection{Anti-Toxicity Experiment Design}

We have previously reported that $10 \mathrm{mg} / \mathrm{L}(\sim 0.1 \mathrm{mM})$ of nano-ZnO exerts significant toxicity effects on the metabolic activity of N. europaea $[15,30]$. Therefore, $0.1 \mathrm{mM}$ of nano- $\mathrm{ZnO}$ was chosen to assess the anti-toxicity effects of exogenous QS signalling molecules.

A series of $100 \mathrm{~mL}$ cell culture samples were withdrawn from the chemostat reactor and incubated in $250 \mathrm{~mL}$ sterile flasks for batch testing. A sterile $\left(\mathrm{NH}_{4}\right)_{2} \mathrm{SO}_{4}$ solution was added to all bottles to give a final $\mathrm{NH}_{4}{ }^{+}-\mathrm{N}$ concentration of $50 \mathrm{mg} / \mathrm{L}$. One bottle was used as the control and it had no NPs or AHL added. Either nano- $\mathrm{ZnO}$ or $\mathrm{C}_{6}$-oxo-HSL was added to two of the bottles. To the other four bottles, both $0.1 \mathrm{mM}$ nano-ZnO and $0.01,0.1,0.5$, or $1 \mu \mathrm{M} \mathrm{C}_{6}$-oxo-HSL were added. Given the possible effects of DMSO on cell metabolic activity, only DMSO was added to another three bottles at $0.03,0.17$, or $0.33 \%(v / v$, Table 1$)$. After $6 \mathrm{~h}$ of incubation at $25^{\circ} \mathrm{C}$ in the dark, the cultures were sampled for analysis. It can be seen from Table 1 that DMSO content up to $0.33 \%$ showed no significant $(p>0.05)$ adverse effects on cell density, membrane integrity, or AOR.

Table 1. Effects of dimethylsulfoxide (DMSO) solvent (no N-acyl-homoserine lactones (AHLs) addition) on cell density, membrane integrity, and ammonia oxidation rate (AOR).

\begin{tabular}{ccccc}
\hline $\begin{array}{c}\text { DMSO Content } \\
(\boldsymbol{v} / \boldsymbol{v})\end{array}$ & $\begin{array}{c}\text { Corresponding AHLs } \\
\text { Content }(\boldsymbol{\mu M})\end{array}$ & $\begin{array}{c}\text { Cell Density } \\
\left(\mathbf{l g}\left(\mathbf{m L}^{-\mathbf{1}}\right)\right)\end{array}$ & $\begin{array}{c}\text { Membrane } \\
\text { Integrity (\%) }\end{array}$ & $\begin{array}{c}\text { AOR (10 } \\
\mathbf{N} / \mathbf{L} / \mathbf{m i n})\end{array}$ \\
\hline $0 \%($ Control) & 0 & $8.49 \pm 0.30$ & $98.98 \pm 0.07$ & $9.07 \pm 0.08$ \\
$0.33 \%$ & 1 & $8.45 \pm 0.48^{*}$ & $98.08 \pm 0.23 *$ & $8.58 \pm 0.58^{*}$ \\
$0.17 \%$ & 0.5 & $8.46 \pm 0.20^{*}$ & $98.74 \pm 0.43^{*}$ & $9.04 \pm 0.30^{*}$ \\
$0.03 \%$ & 0.1 & $8.48 \pm 0.50^{*}$ & $98.22 \pm 1.35^{*}$ & $8.63 \pm 0.52 *$ \\
\hline
\end{tabular}

Note: ${ }^{* \prime}$ means no significant difference $(p>0.05)$ in comparison to the control.

\subsection{Analytical Methods}

$\mathrm{NH}_{4}{ }^{+}-\mathrm{N}$ and $\mathrm{NO}_{2}{ }^{-}-\mathrm{N}$ concentrations were quantified using standard methods [31]. Bacteria were directly counted using a Z30000 Helber Counting Chamber (Hawksley, Lancing, UK) with a BX41 microscope (Olympus, Tokyo, Japan). Superoxide dismutase (SOD) activity, which is responsible for oxidative stress quenching, was measured using a SOD Assay Kit (Dojindo Molecular Technologies, Inc. Rockville, MD, USA), following the manufacturer's instructions. Membrane integrity was determined using a LIVE/DEAD ${ }^{\circledR}$ BacLight ${ }^{\mathrm{TW}}$ Kit (Life Technologies, Waltham, MA, USA). Specific AMO enzyme activity, which is responsible for ammonia oxidation, was measured according to previously described procedures [30], and presented as $\mathrm{NO}_{2}{ }^{-}-\mathrm{N}$ production rate per unit of total protein. The concentrations of dissolved $\mathrm{Zn}^{2+}$ released from nano- $\mathrm{ZnO}$ were quantified using an AAnalyst 400 Atomic Absorption Spectrophotometer (PerkinElmer, Norwalk, CT, USA). Briefly, cell cultures were centrifuged at $9300 \mathrm{rpm}$ to remove suspended cells and NPs. The supernatant was then filtered through a $0.22 \mu \mathrm{m}$ membrane filter (Merck Millipore, Billerica, MA, USA) and acidized using $2 \%(v / v) \mathrm{HNO}_{3}$ before $\mathrm{Zn}^{2+}$ measurement.

\subsection{RNA Extraction and Quantitative Reverse Transcription Polymerase Chain Reaction ( $q R T-P C R$ )}

Total RNA was extracted and purified using an RNeasy Mini Kit (Qiagen, Hilden, Germany) and then transcribed into cDNA using a QuantiTect ${ }^{\circledR}$ Reverse Transcription Kit (Qiagen), according to the manufacturer's instructions. The amo A gene, encoding AMO, and the 16S rRNA gene, were quantified using a CFX Connect Real-Time PCR Detection System (Bio-Rad Laboratories, Hercules, CA, USA). The specific primers used for the amoA and $16 \mathrm{~S}$ rRNA genes and the amplification programs have been described previously [30] and are shown in Table 2. The expression level of $a m o A$ was normalized to that of the $16 \mathrm{~S}$ rRNA gene. 
Table 2. Oligonucleotide primers for $a m o A$ and $16 \mathrm{~s}$ rRNA genes and amplification programs used in quantitative reverse transcription polymerase chain reaction (qRT-PCR) quantification.

\begin{tabular}{|c|c|c|c|}
\hline Target Gene & Primer Sequence & Length (bp) & Amplification Procedure \\
\hline amoA & $\begin{array}{l}\text { F: GGACTTCACGCTGTATCTG } \\
\text { R: GTGCCTTCTACAACGATTGG }\end{array}$ & 662 & $\begin{array}{c}\text { Pre-denaturation: } 95^{\circ} \mathrm{C}, 3 \mathrm{~min} \\
\text { Denaturation: } 95^{\circ} \mathrm{C}, 20 \mathrm{~s} \\
\text { Annealing: } 59^{\circ} \mathrm{C}, 30 \mathrm{~s}\end{array}$ \\
\hline 16S rRNA & $\begin{array}{c}\text { F: TCCTACGGGAGGCAGCAGT } \\
\text { R: GGACTACCAGGGTATCTAATCCTGTT }\end{array}$ & 1462 & $\begin{array}{c}\text { Cycle: } 40 \\
\text { Melting curve: from } 55 \text { to } 95^{\circ} \mathrm{C}, 0.1^{\circ} \mathrm{C} / \mathrm{s} \\
\text { Final hold: } 4{ }^{\circ} \mathrm{C}\end{array}$ \\
\hline
\end{tabular}

\subsection{Statistical Test}

All experiments were performed in triplicate. The results are presented as mean \pm standard deviation $(n=3)$. An unpaired two-sample $t$-test was used to assess statistical significance $(p \leq 0.05)$ between the test samples and the control.

\section{Results}

\subsection{Nano-ZnO Characterization}

The NPs' average primary size was characterized to be $97 \pm 38 \mathrm{~nm}$ by SEM imaging on the basis of measurements of 100 random particles (Figure 1). The hydrodynamic diameter size of $0.1 \mathrm{mM}$ nano- $\mathrm{ZnO}$ in the water was $256 \pm 55 \mathrm{~nm}$.
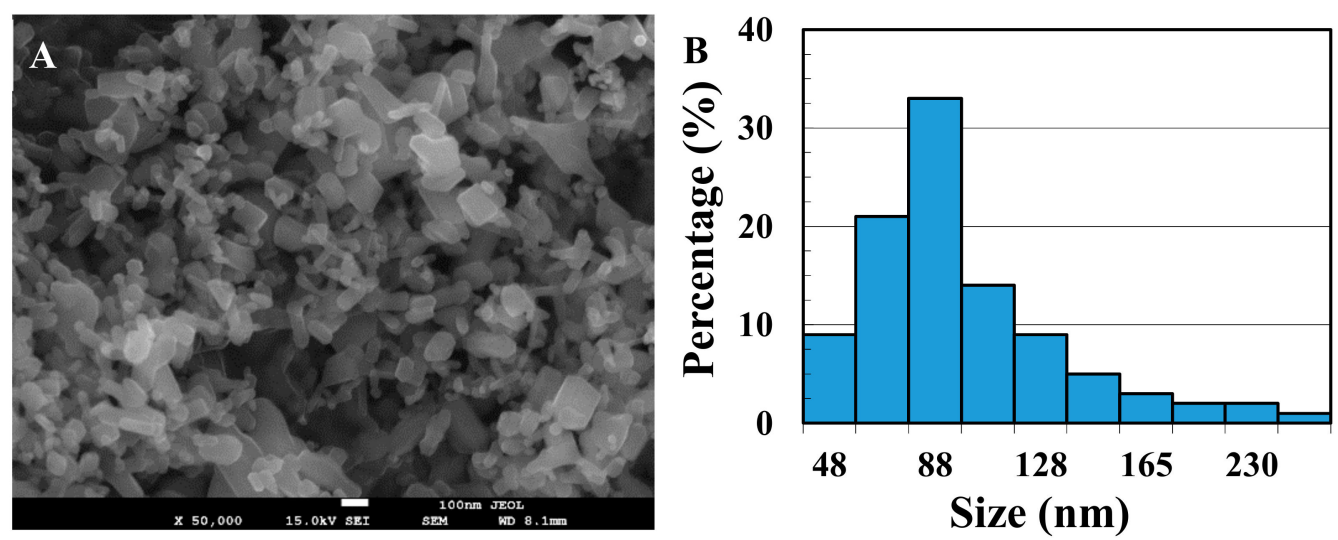

Figure 1. (A) Scanning electron microscope (SEM) imaging of nano-ZnO; (B) nano-ZnO size distribution.

\subsection{Cell Growth and Membrane Integrity}

N. europaea cell density and membrane integrity remarkably decreased by $18.5 \pm 1.8$ and $4.4 \pm 0.7 \%$, respectively, after nano-ZnO stress (Figure 2). The addition of 0.01-0.5 $\mu \mathrm{M} \mathrm{C}_{6}$-oxo-HSL significantly reversed the inhibition effects of nano- $\mathrm{ZnO}$ on cell growth and membrane integrity, which finally showed no significant differences $(p>0.05)$ compared to normal cells. However, $\mathrm{C}_{6}$-oxo-HSL doses as high as $1 \mu \mathrm{M}$ had no effect on cell growth and membrane integrity impaired by nano-ZnO. Moreover, the addition of $1 \mu \mathrm{M} \mathrm{C}_{6}$-oxo-HSL into the $N$. europaea cultures slightly decreased cell concentrations and membrane integrity, but with no statistical differences $(p>0.05)$ compared to normal cells.

\subsection{Ammonia Oxidation Rate (AOR), Ammonia Monooxygenase (AMO) Activity, and amoA Expression}

The nano-ZnO induced inhibition of the ammonia oxidation activity in N. europaea cells was significantly attenuated after the addition of $0.01 \mu \mathrm{M} \mathrm{C}_{6}$-oxo-HSL. The cellular AOR, AMO activity, and $a m o A$ expression increased by $58.7 \pm 7.1,32.3 \pm 1.7$, and $7.3 \pm 5.9 \%$, respectively (Figure $3 \mathrm{~A}-\mathrm{C}$ ), 
after $0.01 \mu \mathrm{M} \mathrm{C}_{6}$-oxo-HSL treatment. However, at concentrations of $0.1-1 \mu \mathrm{M}, \mathrm{C}_{6}$-oxo-HSL did not promote ammonia oxidation activity in N. europaea cells, but even inhibited AOR, AMO activity, and amo $A$ expression with increasing concentrations of $\mathrm{C}_{6}$-oxo-HSL (Figure 3). Moreover, a single $1 \mu \mathrm{M}$ dose of $\mathrm{C}_{6}$-oxo-HSL in normal N. europaea cultures significantly reduced AOR, AMO activity, and amoA expression $(p \leq 0.05)$.
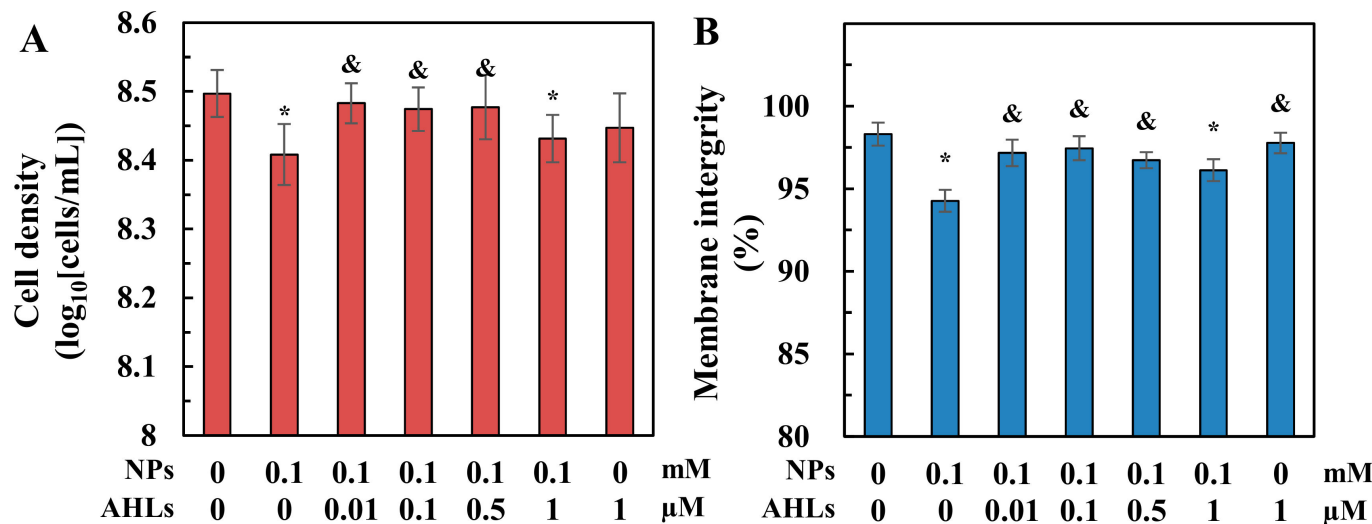

Figure 2. Effects of $N$-acyl-homoserine lactones (AHLs) dosing on $N$. europaea cells after $6 \mathrm{~h}$ of exposure to nano-ZnO: (A) cell density; (B) membrane integrity. ' ${ }^{*}$ ' and ' $\&$ ' indicate significant differences $(p \leq 0.05)$ for test samples compared to normal cells and nano-ZnO-treated cells without AHL addition, respectively.
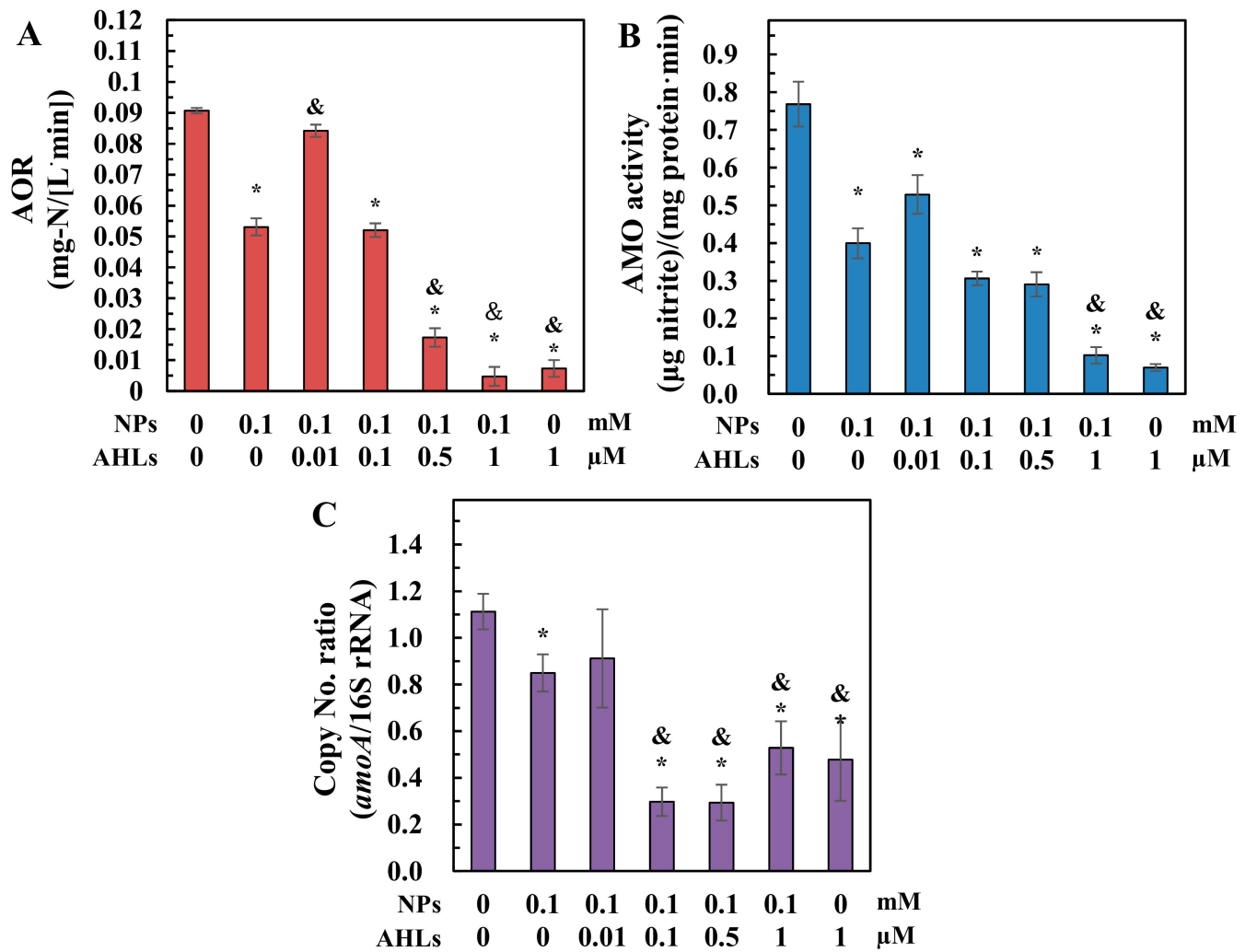

Figure 3. Ammonia oxidation activities in N. europaea cells after $6 \mathrm{~h}$ of exposure to nano-ZnO in the presence of different concentrations of $N$-acyl-homoserine lactones (AHLs): (A) ammonia oxidation rate (AOR); (B) ammonia monooxygenase (AMO) activity; (C) amoA expression. '*' and ' $\&$ ' indicate significant differences $(p \leq 0.05)$ for test samples compared to normal cells and nano-ZnO-treated cells without AHL addition, respectively. 


\subsection{Superoxide Dismutase (SOD) Activity}

Nano-ZnO exposure for $6 \mathrm{~h}$ induced a significant increase $(p \leq 0.05)$ in SOD activity in N. europaea cells (Figure 4). The presence of $\mathrm{C}_{6}$-oxo-HSL at all tested concentrations from 0.01 to $1 \mu \mathrm{M}$ significantly enhanced $(p \leq 0.05)$ SOD activity during 6 h of NP exposure, when compared with either normal cells or nano-ZnO-treated cells. Therefore, AHL addition remarkably enhanced cellular anti-oxidative stress capacities under nano- $\mathrm{ZnO}$ stress.

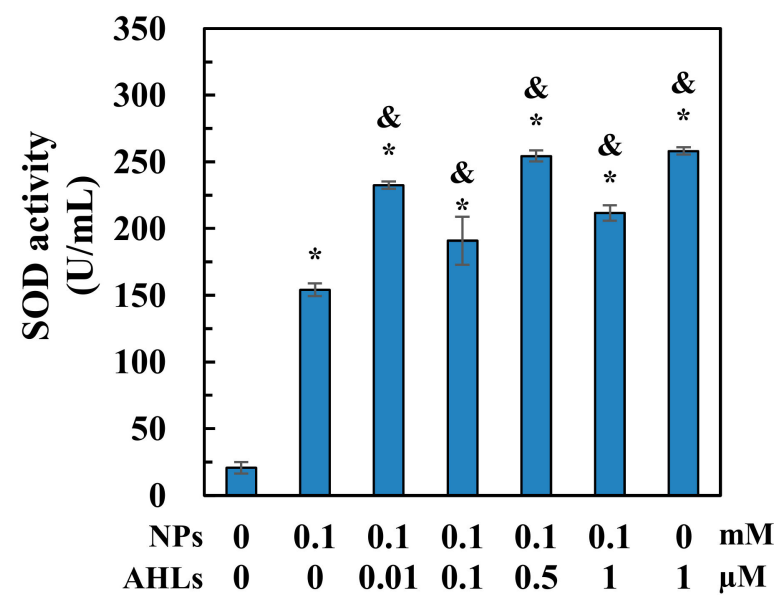

Figure 4. Effects of $N$-acyl-homoserine lactones (AHLs) dose on superoxide dismutase (SOD) activity in N. europaea cells after $6 \mathrm{~h}$ of exposure to nano-ZnO. ' ${ }^{* \prime}$ and ' $\&$ ' indicate significant differences $(p \leq 0.05)$ for test samples compared to normal cells and nano-ZnO-treated cells without AHLs addition, respectively.

\subsection{Nano-ZnO Dissolution}

The dissolved $\mathrm{Zn}^{2+}$ concentration released from nano- $\mathrm{ZnO}$ are shown in Figure 5 when added with AHLs at $0.01-1 \mu \mathrm{M}$ (containing DMSO accordingly at $0.003-0.33 \%$ ). It can be seen that the dissolved $\mathrm{Zn}^{2+}$ concentration was around $0.026 \mathrm{mM}$ in cultures when treated with $0.1 \mathrm{mM} \mathrm{n}-\mathrm{ZnO}$ alone and was not significantly ( $p>0.05, t$-test) affected by AHL (containing DMSO) addition at any concentration tested (Figure 5). Therefore, exogenous addition of AHLs plus DMSO would not dramatically impact the nano- $\mathrm{ZnO}$ dissolution.

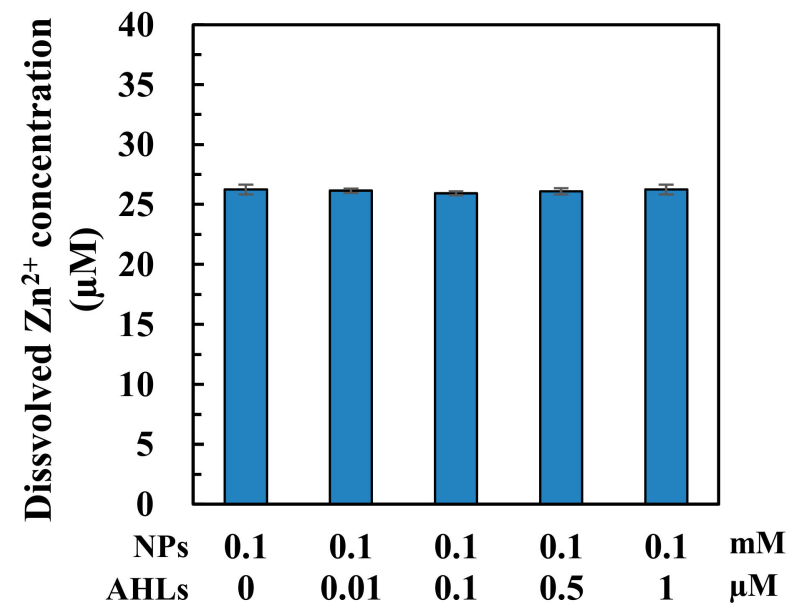

Figure 5. Solubility of $0.1 \mathrm{mM}$ nano-ZnO in the $N$. europaea cultures with $0.01,0.1,0.5$ or $1 \mu \mathrm{M}$ $\mathrm{N}$-acyl-homoserine lactones (AHLs) addition after 6-h incubation. 


\section{Discussion}

The addition of the signalling molecule, $\mathrm{C}_{6}$-oxo-HSL, should help improve bacterial tolerance to nano-ZnO stress and an AHL dose of $0.01 \mu \mathrm{M}$ significantly attenuated the NP-induced inhibition of cell proliferation, membrane integrity, specific AMO activity, and amoA expression in N. europaea (Figures 2 and 3). Ag NPs have been shown to significantly decrease the $\mathrm{C}_{6}$-oxo-HSL concentration and interrupt QS regulation in the Gram-negative bacteria, Pseudomonas syringae and Pantoea stewartii [24]. The addition of AHLs might facilitate QS regulatory functions to enhance bacterial tolerance to nano-ZnO stress and thus rescue the inhibited metabolic activities of N. europaea (Figures 2 and 3 ) by compensating for the potentially depressed AHL levels in the solution. This is supported by the findings that the addition of $0.01 \mu \mathrm{g} / \mathrm{mL}(\sim 0.046 \mu \mathrm{M}) \mathrm{C}_{6}$-oxo-HSL into a starved $N$. europaea culture promotes cell growth through QS regulation during the recovery from starvation [20]. In addition, QS has been shown to mediate the bacterial adaptive responses to graphene oxide stress in biofilm microbial communities [23].

Nano-ZnO has been widely reported to exert bio-toxic effects through physical contact, dissolved $\mathrm{Zn}^{2+}$ release, or ROS production [5,9]. In the present study, dissolved $\mathrm{Zn}^{2+}$ (Figure 5) was expected to greatly contribute to the toxicity of nano- $\mathrm{ZnO}$, despite the fact that the toxic effects of nano- $\mathrm{ZnO}$ on $N$. europaea cells were observed to be higher than those of $\mathrm{Zn}^{2+}$ in our previous study under the same test conditions [32]. However, $\mathrm{Zn}^{2+}$ release from nano- $\mathrm{ZnO}$ was not notably affected by AHL addition (Figure 5) and is, therefore, not likely to be responsible for the observed change in NP cytotoxicity. In addition, nano-ZnO was expected to induce ROS generation, even in the dark, although illumination generally increases ROS concentrations [33,34]. The generated ROS could induce oxidative stress and exert negative impacts on microbes, such as membrane impairment, DNA/RNA damage, lipid peroxidation, and enzyme activity inhibition [35]. The observed increase of SOD activity (Figure 4), which is actively involved in ROS quenching and antioxidant defences [36], after AHL addition, suggested the potential involvement of QS regulation in the oxidative stress tolerance enhancement in N. europaea cultures in response to nano- $\mathrm{ZnO}$ exposure.

N. europaea cells have been shown to fight against nano- $\mathrm{ZnO}$ toxicity through the transcriptional regulation of a diverse range of functional genes and the associated biological pathways [15,37]. The addition of $0.01 \mu \mathrm{M}$ AHLs may have induced QS-mediated gene expressions to rescue the metabolic activities inhibited by nano-ZnO (Figures 2 and 3). For example, diverse membrane metabolism regulation, including osmotic equilibrium adjustment, structure preservation, and membrane transport, are actively involved in the cellular tolerance and adaption to nano- $\mathrm{ZnO}$ exposure [37]. Exogenous supplementation of AHL might potentially induce the regulation of membrane metabolism to resist nano-ZnO stress and thus, alleviate the membrane impairment (Figure 2B). Besides, nano-ZnO-treated cells could activate the transcription of relevant enzymes, such as thioredoxin, DNA repair enzymes, and extracytoplasmic function sigma regulator, to alleviate ROS-induced oxidative stress [15]. In this study, AHL addition might also help improve cellular ROS-quenching capacity, as indicated by the enhanced SOD activity (Figure 4). Furthermore, the amoA gene, encoding AMO, was up-regulated by $7.3 \%$ after the addition of $0.01 \mu \mathrm{M}$ AHLs (Figure 3C). Stimulation of amo $A$ transcription is considered as an antioxidant response to overcome the loss of AMO activity under nano- $\mathrm{ZnO}$ and $\mathrm{Zn}^{2+}$ stress $[15,38]$. Therefore, AHL treatment probably improved the antioxidant potential of NP-stressed cells by regaining the depressed AMO and ammonia oxidation activities (Figure 3A,B).

AHLs displayed a dose-correlative impact on nano- $\mathrm{ZnO}$ toxicity, and increasing the concentration of AHL did not always favour the tolerance of cells to NP stress. Interestingly, exogenous dosing of AHLs at 0.1-0.5 $\mu \mathrm{M}$ only improved cell density and membrane integrity under nano-ZnO stress, while metabolic functions, including AOR, AMO activity and amo $A$ expression, were still inhibited or even deteriorated further (Figures 2 and 3). These results indicated that QS regulation for stress tolerance was dependent on the AHL dosing concentration. An increase in AHL concentration was expected to be immediately perceived by N. europaea cells, resulting in their coordination as a group [18] to fight against NP exposure. Thus, AHLs dosing at $0.1-0.5 \mu \mathrm{M}$ were not expected to cause notable reductions in cell density and membrane integrity (Figure 2). However, Batchelor et al. [20] reported 
that increasing the concentration of $\mathrm{C}_{6}$-oxo-HSL decreases its growth- and activity-promoting effects on N. europaea. Therefore, it is possible that a higher dose of AHLs might compromise the QS regulation effects on N. europaea cells for NP stress resistance, such as the impaired AOR, AMO activity, and amoA expression seen in this study (Figure 3). With further increase of AHL concentration up to $1 \mu \mathrm{M}$, the alleviation of QS regulation effect might even exacerbate nano- $\mathrm{ZnO}$ toxicities, which finally resulted in the observed inhibitions on all cellular metabolic activities (Figures 2 and 3).

The reason for the compromised QS regulation effects with increasing AHL concentrations observed by Batchelor et al. [20] and in this study remains unclear. One possible explanation is that $N$. europaea is generally an autotrophic bacterium that lacks key genes necessary for the transport and assimilation of organic substances [39], and it is sensitive to environmental perturbations, including the presence of organic compounds (Hallin et al., 2005; Radniecki et al., 2008; Urakawa et al., 2008). AHLs function not only as QS signals, but also as organic substrates. It has been reported that AHLs are assimilated or metabolized by heterotrophic bacteria in activated sludge [40,41]. As monocyclic organic compounds, AHLs at higher concentrations might potentially affect the metabolic and ammonia oxidation activities of autotrophic N. europaea cells, especially when they are stressed by nano-ZnO. The oxic ammonia oxidation rate of $N$. europaea cells has been shown to significantly decrease by approximately $45 \%$, without bacterial growth, in the presence of the small-molecule organic compound, fructose [42]. Therefore, a higher dose of AHLs may compromise the effects of QS regulation on cellular tolerance to nano- $\mathrm{ZnO}$ or even exert toxic effects on cells.

\section{Conclusions}

This study preliminarily examined the effects of exogenous AHL on a typical ammonia oxidizer-N. europaea under nano-ZnO stress. AHL displayed a dose-correlative impact on cellular tolerance to nano- $\mathrm{ZnO}$ exposure, and AHL at a dose of $0.01 \mu \mathrm{M}$ significantly alleviated the acute nanotoxicities. Moreover, AHL addition notably enhanced cellular anti-oxidative stress capacities. The findings in this study provide novel insights into the development of QS regulation strategies to alleviate NP toxicity and its environmental risk.

Author Contributions: Conceptualization, J.W. and R.Y.; Data curation, J.W. and R.Y.; Formal analysis, J.W., H.G., J.Y. and Y.C.; Funding acquisition, R.Y. and G.Z.; Investigation, J.W., H.G., J.Y. and Y.C.; Methodology, J.W., H.G., J.Y. and Y.C.; Project administration, R.Y.; Resources, R.Y. and G.Z.; Software, J.W. and J.Y.; Supervision, R.Y. and Z.D.; Validation, J.W. and R.Y.; Visualization, J.W. and Y.C.; Writing—original draft, J.W.; Writing—review and editing, J.W., J.Y., R.Y. and Z.D.

Funding: This work was funded by the National Natural Science Foundation of China (No. 51678134 and No. 51578132), the Natural Science Foundation of Jiangsu Province, China (BK20171154), Key Project of Environmental Protection Research Program of Department of Ecology and Environment of Jiangsu Province, China (No. 2017006), Nanjing Science and Technology Planning Project of Nanjing Science and Technology Committee of Jiangsu Province, China (No. 201716003), and the Fundamental Research Funds for the Central Universities.

Acknowledgments: We sincerely thank Scientific Research Foundation of Graduate School of Southeast University for the financial support to this study. We thank Lina $\mathrm{Xu}$ and Hui Wang from Southeast University for the technical assistance in SEM imaging and atomic absorption spectrophotometry analysis. We also sincerely thank Professor Chang-ping Yu from Chinese Academy of Science for providing N. europaea ATCC 19718 strain.

Conflicts of Interest: The authors declare no conflict of interest. 


\section{Abbreviations}

$\begin{array}{ll}\text { MNPs } & \text { metallic nanoparticles } \\ \text { nano-ZnO } & \text { ZnO nanoparticle } \\ \text { BNR } & \text { biological nitrogen removal } \\ \text { AOB } & \text { ammonia-oxidizing bacteria } \\ \text { QS } & \text { quorum sensing } \\ \text { AI } & \text { autoinducer } \\ \text { 3-oxo-C }{ }_{6} \text {-HSL } & \text { N-3-oxo-hexanoyl-homoserine lactone } \\ \text { AHL } & N \text {-acyl-homoserine lactone } \\ \text { AOR } & \text { ammonia oxidation rate } \\ \text { DMSO } & \text { dimethylsulfoxide } \\ \text { DO } & \text { dissolved oxygen } \\ \text { SOD } & \text { superoxide dismutase } \\ \text { AMO } & \text { ammonia monooxygenase } \\ \text { qRT-PCR } & \text { quantitative reverse transcription polymerase chain reaction }\end{array}$

\section{References}

1. Roco, M.C. The long view of nanotechnology development: The National Nanotechnology Initiative at 10 years. J. Nanopart. Res. 2011, 13, 427-445. [CrossRef]

2. Joo, S.H.; Zhao, D. Environmental dynamics of metal oxide nanoparticles in heterogeneous systems: A review. J. Hazard. Mater. 2017, 322, 29-47. [CrossRef] [PubMed]

3. The JRC Nanomaterials Repository webpage. List of Nanomaterials in the JRC Nanomaterials (NM) Repository. 2016. Available online: https://ec.europa.eu/jrc/en/scientific-tool/jrc-nanomaterials-repository.

4. Wang, Z.L. Zinc oxide nanostructures: Growth, properties and applications. J. Phys. Condens. Matter 2004, 16, R829-R858. [CrossRef]

5. Ma, H.; Williams, P.L.; Diamond, S.A. Ecotoxicity of manufactured ZnO nanoparticle-A review. Environ. Pollut. 2013, 172, 76-85. [CrossRef] [PubMed]

6. Wen, X.; He, Y.; Chen, C.; Liu, X.; Wang, L.; Yang, B.; Leng, M.; Song, H.; Zeng, K.; Li, D.; et al. Magnetron sputtered $\mathrm{ZnO}$ buffer layer for $\mathrm{Sb}_{2} \mathrm{Se}_{3}$ thin film solar cells. Sol. Energy Mater. Sol. Cells 2017, 172, 74-81. [CrossRef]

7. Bhattacharya, J.; Peer, A.; Joshi, P.H.; Biswas, R.; Dalal, V.L. Blue photon management by inhouse grown $\mathrm{ZnO}: \mathrm{Al}$ cathode for enhanced photostability in polymer solar cells. Sol. Energy Mater. Sol. Cells 2018, 179, 95-101. [CrossRef]

8. Leitch, M.E.; Casman, E.; Lowry, G.V. Nanotechnology patenting trends through an environmental lens: Analysis of materials and applications. J. Nanopart. Res. 2012, 14. [CrossRef]

9. Kumar, R.; Umar, A.; Kumar, G.; Nalwa, H.S. Antimicrobial properties of ZnO nanomaterials: A review. Ceram. Int. 2017, 43, 3940-3961. [CrossRef]

10. Keller, A.A.; McFerran, S.; Lazareva, A.; Suh, S. Global life cycle releases of engineered nanomaterials. J. Nanopart. Res. 2013, 15. [CrossRef]

11. Wu, J.; Zhu, G.; Yu, R. Fates and impacts of nanomaterial contaminants in biological wastewater treatment system: A review. Water Air Soil Pollut. 2018, 229. [CrossRef]

12. Wang, D.; Chen, Y. Critical review of the influences of nanoparticles on biological wastewater treatment and sludge digestion. Crit. Rev. Biotechnol. 2016, 36, 816-828. [CrossRef] [PubMed]

13. Wang, S.T.; Li, S.P.; Wang, W.Q.; You, H. The impact of zinc oxide nanoparticles on nitrification and the bacterial community in activated sludge in an SBR. RSC Adv. 2015, 5, 67335-67342. [CrossRef]

14. Wilke, C.M.; Tong, T.; Gaillard, J.F.; Gray, K.A. Attenuation of microbial stress due to nano-Ag and nano-TiO 2 interactions under dark conditions. Environ. Sci. Technol. 2016, 50, 11302-11310. [CrossRef] [PubMed]

15. Yu, R.; Wu, J.; Liu, M.; Chen, L.; Zhu, G.; Lu, H. Physiological and transcriptional responses of Nitrosomonas europaea to $\mathrm{TiO}_{2}$ and $\mathrm{ZnO}$ nanoparticles and their mixtures. Environ. Sci. Pollut. Res. 2016, 23, 13023-13034. [CrossRef] [PubMed]

16. Wilke, C.M.; Gaillard, J.-F.; Gray, K.A. The critical role of light in moderating microbial stress due to mixtures of engineered nanomaterials. Environ. Sci. Nano 2018, 5, 96-102. [CrossRef] 
17. Zhang, W.; Li, C. Exploiting quorum sensing interfering strategies in gram-negative bacteria for the enhancement of environmental applications. Front. Microbiol. 2016, 6. [CrossRef] [PubMed]

18. Papenfort, K.; Bassler, B.L. Quorum sensing signal-response systems in gram-negative bacteria. Nat. Rev. Microbiol. 2016, 14, 576. [CrossRef] [PubMed]

19. Chen, H.; Li, A.; Cui, D.; Wang, Q.; Wu, D.; Cui, C.; Ma, F. N-Acyl-homoserine lactones and autoinducer-2-mediated quorum sensing during wastewater treatment. Appl. Microbiol. Biot. 2018, 102, 1119-1130. [CrossRef]

20. Batchelor, S.E.; Cooper, M.; Chhabra, S.R.; Glover, L.A.; Stewart, G.S.; Williams, P.; Prosser, J.I. Cell density-regulated recovery of starved biofilm populations of ammonia-oxidizing bacteria. Appl. Environ. Microbiol. 1997, 63, 2281-2286.

21. Li, A.J.; Hou, B.L.; Li, M.X. Cell adhesion, ammonia removal and granulation of autotrophic nitrifying sludge facilitated by $\mathrm{N}$-acyl-homoserine lactones. Bioresour. Technol. 2015, 196, 550-558. [CrossRef]

22. Tan, C.H.; Koh, K.S.; Xie, C.; Tay, M.; Zhou, Y.; Williams, R.; Ng, W.J.; Rice, S.A.; Kjelleberg, S. The role of quorum sensing signalling in EPS production and the assembly of a sludge community into aerobic granules. ISME J. 2014, 8, 1186-1197. [CrossRef]

23. Zhang, Y.; Li, N.; Wang, M.; Feng, H.; Xu, C.; Xu, F. Interference of non-lethal levels of graphene oxide in biofilm formation and adaptive response of quorum sensing in bacteria. Environ. Sci. Nano 2018, 5, 2809-2818. [CrossRef]

24. Mohanty, A.; Tan, C.H.; Cao, B. Impacts of nanomaterials on bacterial quorum sensing: Differential effects on different signals. Environ. Sci. Nano 2016, 3, 351-356. [CrossRef]

25. Gu, A.Z.; Pedros, P.B.; Kristiansen, A.; Onnis-Hayden, A.; Schramm, A. Nitrifying community analysis in a single submerged attached-growth bioreactor for treatment of high-ammonia waste stream. Water Environ. Res. 2007, 79, 2510-2518. [CrossRef] [PubMed]

26. Burton, E.O.; Read, H.W.; Pellitteri, M.C.; Hickey, W.J. Identification of acyl-homoserine lactone signal molecules produced by Nitrosomonas europaea strain schmidt. Appl. Environ. Microbiol. 2005, 71, 4906-4909. [CrossRef] [PubMed]

27. Wu, J.; Zhan, M.; Chang, Y.; Su, Q.; Yu, R. Adaption and recovery of Nitrosomonas europaea to chronic $\mathrm{TiO}_{2}$ nanoparticle exposure. Water Res. 2018, 147, 429-439. [CrossRef] [PubMed]

28. Chong, G.; Kimyon, O.; Rice, S.A.; Kjelleberg, S.; Manefield, M. The presence and role of bacterial quorum sensing in activated sludge. Microb. Biotechnol. 2012, 5, 621-633. [CrossRef] [PubMed]

29. Wu, J.; Chang, Y.; Gao, H.; Liang, G.; Yu, R.; Ding, Z. Responses and recovery assessment of continuously cultured Nitrosomonas europaea under chronic $\mathrm{ZnO}$ nanoparticle stress: Effects of dissolved oxygen. Chemosphere 2018, 195, 693-701. [CrossRef] [PubMed]

30. Yu, R.; Wu, J.; Liu, M.; Zhu, G.; Chen, L.; Chang, Y.; Lu, H. Toxicity of binary mixtures of metal oxide nanoparticles to Nitrosomonas europaea. Chemosphere 2016, 153, 187-197. [CrossRef] [PubMed]

31. SEPAC. Methods for Monitor and Analysis of Water and Wastewater, 4th ed.; China Environmental Science Press: Beijing, China, 2002. (In Chinses)

32. Liu, M.T.; Yu, R.; Chen, L.H.; Wu, J.K. Biological effects of typical metal oxide nanoparticles on Nitrosomonas europaea. Chin. Environ. Sci. 2015, 35, 190-195.

33. Bhuvaneshwari, M.; Iswarya, V.; Archanaa, S.; Madhu, G.M.; Kumar, G.K.S.; Nagarajan, R.; Chandrasekaran, N.; Mukherjee, A. Cytotoxicity of ZnO NPs towards fresh water algae Scenedesmus obliquus at low exposure concentrations in UV-C, visible and dark conditions. Aquat. Toxicol. 2015, 162, $29-38$. [CrossRef] [PubMed]

34. Prasanna, L.V.; Vijayaraghavan, R. Insight into the mechanism of antibacterial activity of ZnO: Surface defects mediated reactive oxygen species even in the dark. Langmuir 2015, 31, 9155-9162. [CrossRef] [PubMed]

35. Wu, V.C.H. A review of microbial injury and recovery methods in food. Food Microbiol. 2008, 25, 735-744. [CrossRef] [PubMed]

36. Bowler, C.; Montagu, M.V.; Inze, D. Superoxide dismutase and stress tolerance. Ann. Rev. Plant Physiol. Plant Mol. Biol. 1992, 43, 83-116. [CrossRef]

37. Wu, J.; Lu, H.; Zhu, G.; Chen, L.; Chang, Y.; Yu, R. Regulation of membrane fixation and energy production/conversion for adaptation and recovery of $\mathrm{ZnO}$ nanoparticle impacted Nitrosomonas europaea. Appl. Microbiol. Biotechnol. 2017, 101, 2953-2965. [CrossRef] [PubMed] 
38. Radniecki, T.S.; Semprini, L.; Dolan, M.E. Expression of merA, amoA and hao in continuously cultured Nitrosomonas europaea cells exposed to zinc chloride additions. Biotechnol. Bioeng. 2009, 102, 546-553. [CrossRef]

39. Chain, P.; Lamerdin, J.; Larimer, F.; Regala, W.; Lao, V.; Land, M.; Hauser, L.; Hooper, A.; Klotz, M.; Norton, J.; et al. Complete genome sequence of the ammonia-oxidizing bacterium and obligate chemolithoautotroph Nitrosomonas europaea. J. Bacteriol. 2003, 185, 2759-2773. [CrossRef]

40. Leadbetter, J.R.; Greenberg, E.P. Metabolism of acyl-homoserine lactone quorum-sensing signals by Variovorax paradoxus. J. Bacteriol. 2000, 182, 6921-6926. [CrossRef]

41. Huang, J.J.; Han, J.I.; Zhang, L.H.; Leadbetter, J.R. Utilization of acyl-homoserine lactone quorum signals for growth by a soil Pseudomonad and Pseudomonas aeruginosa PAO1. Appl. Environ. Microbiol. 2003, 69, 5941-5949. [CrossRef]

42. Hommes, N.G.; Sayavedra-Soto, L.A.; Arp, D.J. Chemolithoorganotrophic growth of Nitrosomonas europaea on fructose. J. Bacteriol. 2003, 185, 6809. [CrossRef]

(C) 2019 by the authors. Licensee MDPI, Basel, Switzerland. This article is an open access article distributed under the terms and conditions of the Creative Commons Attribution (CC BY) license (http://creativecommons.org/licenses/by/4.0/). 